\title{
PHENOMENON OF TRANSPARENCY: CITYSCAPE TRANSFORMATIONS MAPPING RESEARCH ISSUES
}

\begin{abstract}
A B S T R A C T
The aim of this article is to propose methodological layers, developed during $\mathrm{PhD}$ research, which explore the impact of transparency in relation to the transformations of the city. First two parts of the process investigate the impact of transparency by decoding (in) visible cityscape transformations, towards mapping the fragments of intersections between individual atmospheres. After merging static and dynamic activity states of the phenomenon of transparency, the fourth layer shifts perception by zooming in and out - from the city as a whole, towards its individual spatial values and specific aspects. Analysis ends with (de)fragmentation reading via drawing as a critical tool for resolving spatial conflicts. Layer by layer, the proposed methodology determines the influence of the phenomenon of transparency on architectural design process, and its importance for rethinking and understanding the problems and potentials of cityscape transformations.
\end{abstract}




\section{INTRODUCTION}

New collisions of elements within space ever more strongly demonstrate the disruption of unique entities via the transformations of any micro homogeneous space to the heterogeneous one. The unique, compact, solid structures, the ones that can not be disassembled almost disappeared. Rapid progress of urban changes has influenced the city so hasty that such complex phenomena often remain unexplained. Moreover, the possibility for their transformation into new concepts has not yet been explored. The importance of this issue arises from the fact that the city, as the most complex artifact, can be regarded as the most representative example of a heterogeneous structure - diverse, composed of parts of different kinds; having widely dissimilar elements or constituents. The constant transformability of the urban structure has its own dynamic rhythm. This process, observed by architects, can be (de)fragmented and used in architecture as a polygon for new research opportunities, and as a source for unpredictable situations, to challenge the architects at the beginning of the architectural task. The secondary problem that consequently arises, is the rejection of the existing conditions as an uncritical attitude of architectural practices towards these spatial conflicts, with its main explanation being the impossibility of comprehending the chaotic appearance of the context in question. The implications are directly reflected to our built environment, i.e. to the ground of the contemporary city, leading to the ever more perplexedly spatial situations, and thus, to further expansions of the field for new unconsidered reactions to the existing space.

\section{DECODING THE (IN)VISIBLE: UNPREDICTABLE CITYSCAPE TRANSFORMATIONS}

The first part of our analysis focuses on a whole, such as the ground of the city, instead of a phenomenological research of a single object. The ground of the city is a result of all built structures that along with the natural ground form a complex system (of elements and processes). Starting from the fact that building places essentially belong to architecture, in the city - the artificial speaks for the natural. Today, by investigating the city, we come to realize that the cityscape transformations determine the questions of perception of complexity of one such structure. In that context, cityscape "is the art of giving visual coherence and organization to the jumble of buildings, streets and space that make up the urban environment." Dynamism and static quality of each moment is expressed through the spatiality of the urban landscape. By analyzing and defining the principles of constant changes within the city, we will be gradually revealing the significance of the phenomenon of transparency. During this process, Paul Virilio's significantly 
contributes to the clarification about the changes of material structure and it broadens the general definition of transformation as a dramatic change in form or appearance: alteration, change and modification. "Basically, along with construction techniques, there's always the construction of techniques, that collection of spatial and temporal mutations that is constantly reorganizing both the world of everyday experience and the aesthetic representations of contemporary life. Constructed space, then, is more than simply the concrete and material substance of constructed structures, the permanence of elements and the architectonics of urbanistic details. It also exists as the sudden proliferation and the incessant multiplication of special effects which, along with the consciousness of time and of distances, affect the perception of the environment". ${ }^{3}$

According to the research, instability of the built environment indicates to the potential of uncovered new meanings of urban elements to the design process. The first level of this process will begin with the identification of relevant historical facts that have led to the existing state of the city. History of architecture indicates to certain turning points, in relation to which, the typology of architecture is also shifting. The third typology, which Anthony Vidler defined as the most recent, "is not built up out of separate elements, nor assembled out of objects classified according to use, social ideology, or technical characteristics: it stands complete and ready to be decomposed into fragments", ${ }^{4}$ where the city is "considered as a whole, its past and present revealed in its physical structure. It is in itself and of itself a new typology". According to our criteria, the element does exist, only it is not visibly and literally extractable, but it is hidden and requires a new methodology for its extraction. Following Vidler's standpoint, we will be focusing on the interpretation of the fragments of the last (new) typology, under the assumption that these bring about the potentials for initiating architectural concepts. Our attention is not directed towards historical specification, but to the qualities of the existing spaces, where: "The city, that is, provides the material for classification, and the forms of its artifacts over time provide the basis for recomposition". ${ }^{6}$ Having in mind "essential conditions of the city" as "mixture of formal and informal elements and the mixture of order and disorder" we investigate "whether there was a new technique, a way of working with this weakness or incompetence, a potential to reverse the situation, whereby we could no longer claim that we could built a city, but could find other elements with which we could nevertheless create a new form of urban condition. We were not so much thinking about what we could build as analyzing the situation to determine where we would under no circumstances build." ${ }^{8}$ Understanding the cityscape transformations is directed towards overcoming the intersection 
problems of order and disorder, similarities, and dissimilarities in order to reach the extracted common denominator of urban conditions.

\section{TRANSPARENCY OF THE INDIVIDUAL ATMOSPHERES: MAPPED FRAGMENTS INTERSECTIONS}

The complexity of the city is analyzed fragmentarily. It starts from a single image - one flash that reflects the cityscape. This approach doesn't neglect one moment to another, nor is the selected fragment the only sample of space transformation, but the experiment seeks to document and analyse a series of a different changes of the cityscape transformations in order to obtain parameters that would be relevant to a such complex spatiality. Layering a single image of space on pure horizontal and vertical directions is not enough to decode one fragment; but by layering the layered, we are prepared to $\mathrm{read}^{9}$ new meanings of the rhythm of different directions of the cityscape transformations. The proposed methodology doesn't stop the research of one image in the moment of detection of the basic indicators of the change, it requires far deeper research revealing all the finesses of the other fragments that could be important for the intersection with the current image.

The dynamic relationships between elements establish the questions of intersections of those cityscape layers which are not next to each other. Each of unnumbered relationships attracts the new gap that creates a different, energized transparent zone. "Transparency is not simply transparency. Its manifold nuances and complexions invest it with the intriguing artistic potential to express ambivalence". ${ }^{10}$ Comparatively, it is always being observed anew, as it directly relates to the present moment. "Transparency is viewed as an antithesis to all that is concealed; it even allays doubts because nothing remains hidden, everything is revealed. Nonetheless, such seemingly unconditional exposure is still only appearance". ${ }^{11}$ It is impossible to reject the relations that it constantly includes or excludes, exposes or reveals to happenings inside or outside the building, or the urban area... Each of these individual images forms a space around itself, thus producing a scale of different impressions that trigger reactions of our mind and body. Every man creates a distinctive occurrence of his interior space, and for us - a new image. Dominant images tend to combine. ${ }^{12}$ The degree of openness is achieved through transparency, and therefore, the impression of urbanity as well. It is precisely at this level that materiality reflects the human activity, which in turn creates new reality by showing its own actuality. What is this form of life that combines so many different human lives into a single image? Are those traces of lives the ones that should be decoded by the architect as an essence for his (her) emerging ideas? 
"This is the watershed. Up to this point we have presented the environment as occupied territory serving the legitimate social and business needs of people and irrigated by traffic routes. Now arises the natural corollary that if outdoors is colonized than the people who do this will attempt to humanize the landscape in just the same way they already do for the interiors. At this point we can find little difference between the two, and the terms Indoor Landscape and Outdoor Room make sense". ${ }^{13}$ The study of relations from the inside to outside is necessary to complete the intent of cityscape transformation mapping. What might prove especially useful for architects is to intersect the atmospheres of human activities in different spaces, that is, to map serial vision ${ }^{14}$ of them as a specific layer of the cityscape transformations. "Although from a scientific or commercial point of view the town may be a unity, from our optical viewpoint we have split it into two elements: the existing view and the emerging view. In the normal way this is an accidental chain of events and whatever significance may arise out of the linking of views will be fortuitous. Suppose, however, that we take over this linking as a branch of the art of relationship; then we are finding a tool with which human imagination can begin to mould the city into a coherent drama. The process of manipulation has begun to turn the blind facts into a taut emotional situation". ${ }^{15}$ According to our research existing and emerging views are not two elements, but an elusive space or the transformation of it - like a flash between the two such close moments where we try to include both in order to start decoding the fragment of reality.

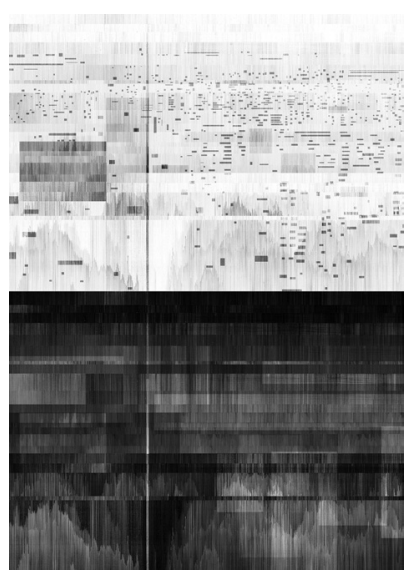

Figure 1. Snežana Zlatković, Phenomenon of Transparency: Cityscape Transformations Mapping, The City of New Belgrade, Experiment 1, 2016, Digital collage of hand pencil drawings, The Books of Drawings (maps), 2013-2016

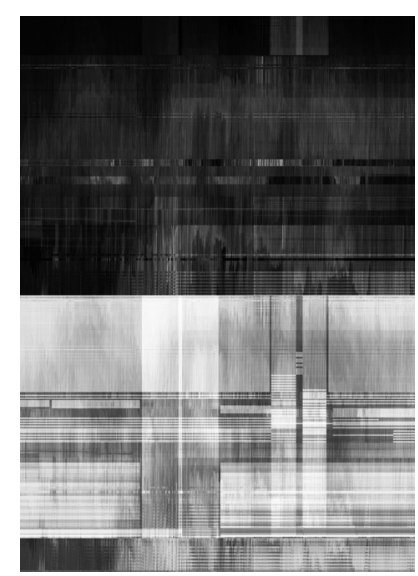

Figure 2. Snežana Zlatković, Phenomenon of Transparency: Cityscape Transformations Mapping, The City of New Belgrade, Experiment 3, 2016, Digital collage of hand pencil drawings, The Books of Drawings (maps), 2013-2016

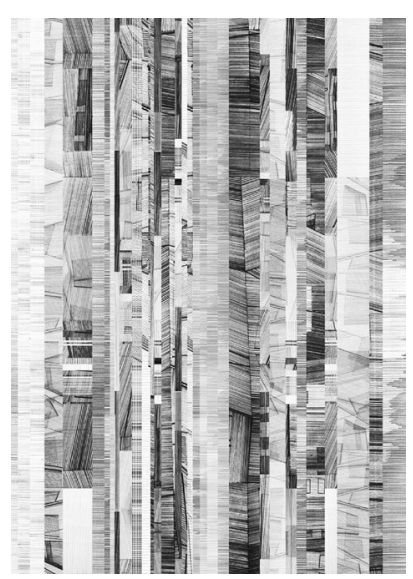

Figure 3. Snežana Zlatković, The City of Reflection, Experiment 8 detail, 2016, Digital collage of hand pencil drawings, The Books of Drawings (maps), 2013-2016 
STATIC AND DYNAMIC PHENOMENON:

\section{MERGING BASIC ACTIVITY STATES}

This kind of energised zones develop specific relationship between the volumes that could be connected through methodology. The absence of the static part of a volume occurs in the moment when the void becomes the main active field - space, mass, line appear through transparency as a new kind of an active image. Spatial tensions within concrete reality will be researched in two parallel aspects. The first one is Bernhard Hoesli's transparent-form organization as an instrument of design, ${ }^{16}$ and the second one considers the basic characteristic of transparency, such as: ambiguity, vagueness, folding, intersection. According to Colin Rowe and Robert Slutzky transparency "implies more than an optical characteristic, it means a broader spatial order [...] means a simultaneous perception of different spatial locations". ${ }^{17}$ However, they further establish the basic distinction: "Transparency may be an inherent quality of substance, as in a glass curtain wall; or it may be an inherent quality of organisation. One can, for this reason, distinguish between a literal and phenomenal transparency". ${ }^{18}$ On the other hand, our study is not based on making clear distinctions within the phenomenon of transparency, but on establishing the connections between actions in both identified states. Without putting literal transparency ahead of the phenomenal one, or vice versa, but by consciously taking both into account, we are on the verge of capturing the urban phenomena as a complete entity.

In order to explain the phenomenon of transparency, we start from two basic activity states. First, we analyse a fragment of the city separately for each of the states. After that, we merge them through drawings according to how they have transformed and changed. The first state is the result of a historical process: a physical closed, static structure that might be subjected to possible changes in the future. It is the product of various design processes, as well as of unplanned constructions. Together, these form a unique urban whole. The second state of activity belongs to the dynamism of the city structure. Drawing can articulate the variability and rhythm within the structure of a city - it is a series of single moments and lives that cannot be repeated, but might prove valuable for the process.

SHIFTING THE DISTANCE :

ZOOM IN - ZOOM OUT

Color is reflecting the volumetric ${ }^{19}$ ambivalence of space through the phenomenon of transparency. It seems that everything that is absent becomes present through the dynamic relationship of urban structural elements. The 
emptiness is a full field with the endless network of spatial relationships. Countless air negatives of the static and rigid parts of the urban area become recognised through the images of limitless color value of the indoor landscape where the interpretation of the process might be initiated, but it could never end. Does each new situation therefore transform the cityscape in order to display all different atmospheres of habitation? What is a key factor in the methodological process to understand the collection and the appearance of individuality? Does the space provide otherness to be another? Or is it an act of space transformation? How does this shift of an individual and family vibes affect the review of the entire situation? ${ }^{20}$

Overall, is there a distance between the micro and macro atmospheres when we analyse the cityscape transformation, or is it about a continuous concatenation of both levels of the atmospheres in order to implement the more precise experiment? For our research the problem of transformation can be viewed through the number of atmospheric overturns of one of the frozen moments of space, and then to the next moment with all the spaces of the cityscape. The methodology tends to erase the boundary between the points of space network that are analysed, nothing is too far away, nor too close, everything is dispersed and mixed. "Here than we discover a pliability in the scientific solution and it is precisely in the manipulation of this pliability that the art of relationship is made possible. As will be seen, the aim is not to dictate the shape of the town or environment, but it is a modest one: simply to manipulate within the tolerances". ${ }^{21}$ The influence of the phenomenon of transparency has changed the perception of static structure to its final limits, thus constructing differently fragmented architecture.

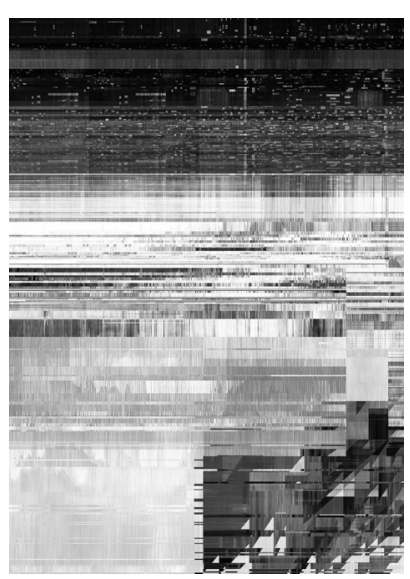

Figure 4. Snežana Zlatković, Habitation - Cityscape - Transformation, Experiment 10 - detail, 2016, Digital collage of hand pencil drawings, The Books of Drawings (maps), 2013-2016

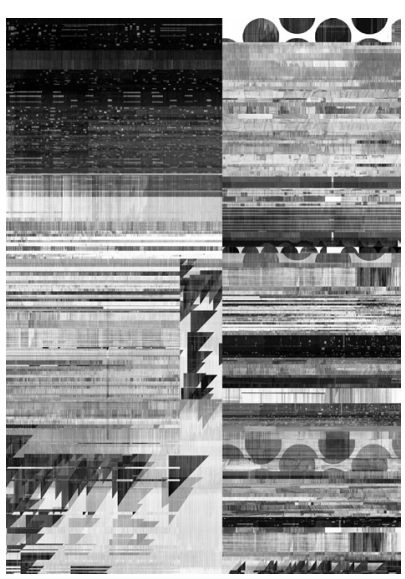

Figure 5. Snežana Zlatković, Habitation - Cityscape - Transformation, Architect's Scale-Experiment 11, Ruler $1-10 / n$-detail, 2016, Digital collage of hand pencil drawings, The Books of Drawings (maps), 2013-2016

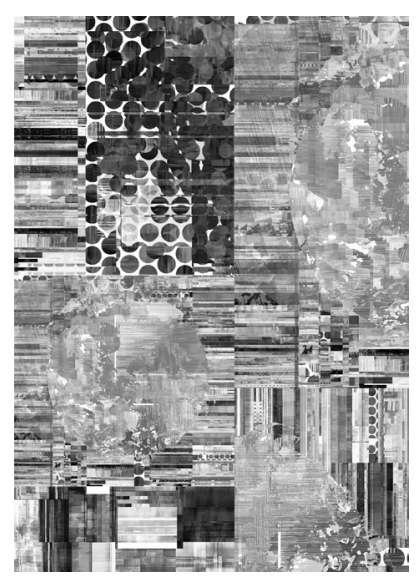

Figure 6. Snežana Zlatković, Micro Macro, Cityscape Transformation Atmospheres, Architect's Scale - Experiment 20-21, Ruler 1-10/n-detail, 2016, Digital collage of hand pencil drawings, The Books of Drawings (maps), 2013-2016 
Methods of encoding levels of transparency through drawing also change our own attitudes to the space being drawn; at the beginning of each new drawing, we are trying to establish the distance of observation in relation to our view of the cityscape's transformations. By drawing, the architect has to be able to analyse and understand the speed of the spatial changes through the drawn process itself. Drawing these spatial traces sets up a basis for the architect to understand how to weave these abstract traces of unexplained phenomena in the future. The methodology captures all specific individual atmospheres of life in the city within a drawing, before the view shifts distance in order to perceive the ground of the city - to summarise all those lives.

\section{(DE ) FRAGMENTATION READING :}

DRAWING AS A CRITICAL TOOL

With two basic states of the phenomenon of transparency (static and dynamic), the methodology produces drawings as a sequence of experiments on cityscape transformations. Before this experiment our focus was on those artistic practices which provide us with another view which can help us identify strongly established connections between subjective associations and the observed objective reality. ${ }^{22}$ A number of artworks offer us valuable insight into the other experiences of the built environment, where we do not see a piece of art only as it is, but as a whole new world that emerges from it; the world that is happening right in front of us, but we have never seen it in this way.

The first results of this experimental methodology are two books of a hundred drawings each, researching scales of transparency. The changes of transparency are explored with subtle, hand-drawn lines extracted from color. These original drawings are then used as a resource material for the next phase of research - the digital processing of images via a series of computerised techniques. Using both analogue drawing techniques and digital image processing brings new opportunities for analysing the complex and chaotic network of cityscape transformations, both working together to make them readable. Architecture makes invisible qualities of the environment to become visible. ${ }^{23}$ In order to comprehend differences, we use the material to expose the immaterial and their relation to the unbuilt. The study of spatial conflicts that are not directly visible through drawing stimulates new points of view and new analysis and finally yields new information. Therefore immateriality depends upon materiality and is based on the intuitive abilities of the observer and a certain level of knowledge and understanding of the phenomenon. Under these circumstances, we can reach the point of mapping transformations of the urban fabric where 
we can establish a common language in the drawing. In order to create a poetic diagram for dynamic mapping, we search for answers in the relationship between the hand-drawing as the first critical tool and the computer as the second one. This relationship between the intuitive trace of a hand and the mechanised processes of digital tools provides our drawn methodology with comprehensive tools to encode any transformation using these techniques (Figs. 1-6). While there is still something incomplete in the analysis when we draw purely by hand, there are many computer techniques that could upgrade these drawings to new levels of information; so that drawing becomes a critical tool to extract and explain the potentials of the layers of transparency within our cities that conventional tools may not address.

Transparency induces us to a specific interpretation of porosity which leads us towards layering and then the layering itself to (de)fragmentation. To a certain sense it is about the fragmentation of transparency as methodological process that examines the cityscape transformation, but then return it to the new state, hereby forming a specific unit which transforms the city according to new discovered element of the architectural analysis. Through the phenomenological reduction of the materiality, the process extracts the immateriality - a completely new level of the observation of cityscape transformation. The viewer often only takes a superficial look of the chaotic appearance of the city, without finding natural depth, and without his/her own phenomenological reduction. Phenomenology enables us to share our everyday experience in a different manner, to express what we $s e e .{ }^{24}$ In order to achieve complex aims we use phenomenological reduction - the reduction of overall conscious experience to its initial, basic experiences. ${ }^{25}$ In the process of understanding the visual, under these circumstances we can reach the new level of the collision between the pure subjectivity and the precise appearance, where the identification of the abstract code is possible.

\section{TOWARDS A SYNTHESIS}

This study of spatial relations, from inside to outside, from micro to macro, stimulates new points of view and new analyses between two ends of the potentials of transparency. Through proposed levels of research, we have determined the crucial influence of the phenomenon of transparency for the process of cityscape transformations mapping in order to understand the chaotic context towards resolving specific spatial conflicts. What used to be immaterial has the potential to become material in another, new form. We use drawing as a critical tool in attempt to provide new readings of decoded, defragmented 
spatial contradictions, to describe what belongs to the phenomenological experience. The invisible constructs links of the existing built environment the hidden order. The role of the phenomenon of transparency is reflected in the fact that essentially separated, dispersed parts of the cityscape transformations are being merged through new traces of thinking. Layer by layer, the drawings are slowly disentangling our field of view into new perceptions by inverting the contradictions, deconstructing the sequences and merging what is seemingly incompatible. Layers of transparency become sections through the cityscape's transformation. Uncontrollable appearances and disappearances of the transfigured spatial volumes, anatomised through drawings, build a new grid of traces, new moves and new rhythms, which could challenge the future organisation of our cities. 
Through the overview of the methodological process the article will refer to different parts of $\mathrm{PhD}$ process. Some of them have been presented in various international and national architectural competitions, conferences and exhibitions. This paper will focus on: Snežana Zlatković, "Phenomenon of Transparency: Cityscape Transformations Mapping," in Drawing Futures: Speculations in Contemporary Drawing for Art and Architecture, eds. Laura Allen and Luke C. Pearson (London: UCL Press and Bartlett School of Architecture, 2016) (in press); Snežana Zlatković, "Phenomenon of Transparency: Active Energy for Becoming Spaces of the City," in On Architecture: Reworking the City through New Architecture: conference proceedings (Belgrade: Sustainable Urban Society Association - STRAND, 2015), 156-176. importance of an individual's perception of the physical and visual elements of urban environment. This concept was first developed in The Architectural Review and later published in a longer form as the Townscape (1961). Townscape is roughly synonymous with cityscape. According to the our research we will use the term cityscape, because it indicates the difference between the words city and town (urban size, density and even modernity). We refer to Cullen's writing about townscape on the back cover of the book. See: Gordon Cullen, The Concise Townscape (London: Architectural Press, 1971).

Paul Virilio, "The Overexposed City," in Rethinking Architecture: A Reader in Cultural Theory, ed. Neil Leach (London: Routledge, 1997), 364. We refer to Vidler's definition of two previous distinct typologies from the middle of the eighteenth century that have informed the production of architecture: “[...] The first returned architecture to its natural origins - a model of primitive shelter [...]. The second, emerging as a result of the Industrial Revolution, assimilated architecture to the world of machine production, finding the essential nature of a building to reside in the artificial world of engines". See: Anthony Vidler, "The Third Typology," in Architecture Theory since 1968, ed. Michael K. Hays (Cambridge, Mass: MIT Press and Columbia University Graduate School of Architecture, 1998), 288; 292.

Ibid., 292.

Ibid., 288.

Rem Koolhaas, "Beyond Delirious," in Theorizing a New Agenda for Architecture: An Anthology of Architectural Theory 1965-1995, ed. Kate Nesbitt (New York: Princeton Architectural Press, 1996), 332 . Ibid.,333.

Reading anatomizes the chaotic composition of different elements, it is a way to extract the essence, to understand something, whereas seeing could be interpreted only literally. Seeing is a necessary condition for further development of the process, but it is oriented only towards the material, whereas reading includes the immaterial as well, and is directed towards explaining the phenomenon and obtaining new conclusions (on the conceptual level) about the object of research. Herzog Jacques and Pierre de Meuron, Treacherous Transparencies: Thoughts and Observations Triggered by a Visit to Farnsworth House (IITAC Press/Actar Publishers: Chicago, New York, 2016), 10 . Ibid., 11.

Gaston Bachelard, The Poetics of Space (Boston: Beacon Press, 1994), 131.

Cullen, The Concise Townscape, 28.

Ibid., 9.

Ibid.

"The attempt to describe buildings or urban patterns independently from their historical context, to see them side by side across periods of stylistic differences and to insist on a common quality in works from widely differing epochs, produced by distinct social, technical and political conditions may disturb or shock and dismay the historian. But of course it is not proposed to remove a particular building from its historical and cultural context; to look for transparency is merely a possibility to disengage part of its characteristic form. 
The concept or transparency invites to see differences that can provide the key to understand qualities of uniqueness or similarity". See: Bernhard Hoesli, "Transparent Form-organization as an Instrument of Design," in Transparency, eds. Colin Rowe and Robert Slutzky (Basel/Boston/ Berlin: Birkhäuser, 1997), 86.

Colin Rowe and Robert Slutzky, "Transparency: Literal and Phenomenal," in Transparency, eds. Colin Rowe and Robert Slutzky (Basel/Boston/Berlin: Birkhäuser, 1997), 23.

Ibid.

Гастон Башлар, Ваздух $u$ снови: оглед $о$ имагинацији кретања (Сремски Карловци/Нови Сад: Издавачка књижарница Зорана Стојановића, 2001), 142.

Our environment is increasingly less the result of carefully planned architectural structures. On the other side, there are those structures that are a product of long-term thinking processes. Both cases have in common two different types of materiality, hiding, within themselves, everyday life and the needs of an ordinary man. The degree of openness is achieved through transparency, and therefore, the impression of urbanity as well. Even when we term this kind of transparency - social transparency, we cannot argue against it being a part of space.

The research establishes a correlation between ongoing artistic practices that interpret the world in which we live today, and the ones that were happening almost a century ago. In some way, the selected cases form the 20th century indicated the formation of the current situation. We started from the examples that, as close as possible, describe the contemporary moment, as well as the modern man within it. These visualizations do not show people, but the architectural images speak on their behalf: Michael Wolf (Architecture Of Density (the Outside Volume Of Hong Kong Inside/ Outside), 2014; The Transparent City, 2008), Paul Klee (Hauptweg und Nebenwege, 1929; Dream City, 1921), Piet Mondrian (New York, New York, 1941-1942; New York City I, 1942; New York City II (unfinished)), Velizar Vasa Mihić (Buket, 1970), Vjenceslav Rihter (SIG 1, AnBsCnDn, 1970; SIG 2, Ay, 1970; Prostorna sistemska grafika, 1997; Prostorna slika 1, 1997), Olafur Eliasson (Your Rainbow Panorama, 2011), etc. The boundary of an architectural image is broken by artistic practices like the previously mentioned ones, thus confirming the importance of the other interpretations, as well as the significance of phenomenological reduction. Ephemerality, constructed by the phenomenon of transparency, gradually takes a new form; towards another architecture. 
Albers, Josef. Interaction of Color: 50th Anniversary Edition. New Haven/London: Yale University Press, 2013.

Bachelard, Gaston. The Poetics of Space. Boston: Beacon Press, 1994.

Башлар, Гастон. Ваздух $и$ снови: оглед $о$ имагинацији кретања. Сремски Карловци/Нови Сад: Издавачка књижарница Зорана Стојановића, 2001.

Burns, Carol J. “On Site: Architectural Preocupations.” In Drawing Building Text: Essays in Architectural Theory, ed. A. Kahn, 146-167. New York: Princeton Architectural Press, 1991.

Cullen, Gordon. The Concise Townscape. London: Architectural Press, 1971.

Desimini, Jill and Waldheim, Charles eds. Cartographic Grounds: Projecting the Landscape Imaginary. New York: Princeton Architectural Press, 2016.

Eliasson, Olafur. "Frictional Encounters." In Paradoxes of Appearing: Essays on Art, Architecture and Philosophy, eds. A. M. Andersen, H. Oxvig, 129-147. Baden: Lars Müller Publishers, 2009.

Eliasson, Olafur and Irwin, Robert. "Take Your Time: A Conversation". In Take Your Time: Olafur Eliasson, ed. M. Grynsztejn, 51-61. San Francisco Museum of Modern Art: Thames and Hudson, 2007.

Heidegger, Martin. “Building, Dwelling, Thinking.” In Rethinking Architecture: A Reader in Cultural Theory, ed. N. Leach, 94-119. London: Routledge, 1997.

Hill, Jonathan. "Philosophical Text: Excerpts from Immaterial Architecture.” In Introducing Architectural Theory: Debating a Discipline, ed. K. Smith, 133-137. New York/London: Routledge, 2012.

Hoesli, Bernhard. "Transparent Form-organization as an Instrument of Design.” In Transparency, eds. Rowe and R. Slutzky, 85-119. Basel/Boston/Berlin: Birkhäuser, 1997.

Jacques, Herzog and de Meuron, Pierre. Treacherous Transparencies: Thoughts and Observations Triggered by a Visit to Farnsworth House. IITAC Press/Actar Publishers: Chicago, New York, 2016.

Koolhaas, Rem. "Beyond Delirious.” In Theorizing a New Agenda for Architecture: An Anthology of Architectural Theory 1965-1995, ed. K. Nesbitt, 332-336. New York: Princeton Architectural Press, 1996.

Leatherbarrow, David. The Roots of Architectural Invention: Site, Enclosure, Materials. Cambridge: Cambridge University Press, 1993.

Leatherbarrow, David. Topographical Stories: Studies in Landscape and Architecture. Cambridge, Mass: The MIT Press, 2000.

Merleau-Ponty, Maurice. Fenomenologija percepcije . Sarajevo: Veselin Masleša, 1978.

Merleau-Ponty, Maurice. The Visible and the Invisible. Evanston: Northwestern University Press, 1968.

Pallasmaa, Juhani and Robinson, Sarah eds. Mind in Architecture: Neuroscience, Embodiment and the Future of Design. Cambridge, Mass. and London: MIT Press, 2015.

Pallasmaa, Juhani. The Eyes of the Skin: Architecture and the Senses. London: Artmedia Press, 2005.

Pallasmaa, Juhani. The Embodied Image: Imagination and Imagery in Architecture. Chichester: John Wiley \& Sons, 2011.

Péréz - Gomez, Alberto, Pallasmaa, Juhani and Holl, Steven. Questions of Perceptions. Phenomenology of Architecture. San Francisco: William K. Stout Publishers, 2006.

Rowe, Colin and Slutzky, Robert. "Transparency: Literal and Phenomenal.” In Transparency, eds. C. Rowe and R. Slutzky, 21-55. Basel/Boston/Berlin: Birkhäuser, 1997.

Uzelac, Milan. Fenomenologija. Novi Sad: Studio Veris, 2009.

Vidler, Anthony. "The Third Typology.” In Architecture Theory since 1968, ed. M. K. Hays, 288294. Cambridge, Mass: MIT Press and Columbia University Graduate School of Architecture, 1998. 
Virilio, Paul. "The Overexposed City.” In Rethinking Architecture: A Reader in Cultural Theory, ed. N. Leach, 358-368. London: Routledge, 1997.

Zanini, Pjero. Značenja granice: prirodna, istorijska i duhovna određenja. Beograd: Clio, 2002.

Zlatković, Snežana. "Phenomenon of Transparency: Cityscape Transformations Mapping." In Drawing Futures: Speculations in Contemporary Drawing for Art and Architecture, eds. L. Allen and L. C. Pearson, London: UCL Press and Bartlett School of Architecture, 2016 (in press)

Zlatković, Snežana. "Phenomenon of Transparency: Active Energy for Becoming Spaces of the City." In On Architecture: Reworking the City through New Architecture: conference proceedings, 156-176. Belgrade: Sustainable Urban Society Association - STRAND, 2015.

Zumthor, Peter. Atmospheres. Architectural Enviroments. Surrounding Objects. Basel/Boston/ Berlin: Birkhäuser, 2006.

Zumthor, Peter and Pallasmaa, Juhani. “Building Atmosphere.” OASE Journal for Architecture 91 (2013). 


\section{FENOMEN TRANSPARENTNOSTI : MAPIRANJE TRANSFORMACIJA GRADSKOG PEJZAŽA - ISTRAŽIVAČKA PITANJA}

\section{Snežana Zlatković}

Cilj ovog članka je da predloži metodološke slojeve razvijene tokom istraživanja za doktorsku disertaciju, koje ispituje uticaj transparentnosti na transformacije grada. Prva dva dela procesa istražuju uticaj transparentnosti dekodiranjem (ne)vidljivih transformacija gradskog pejzaža ka mapiranju fragmenata preseka između individualnih atmosfera. Nakon spajanja aktivnosti statičnih i dinamičnih stanja fenomena transparentnosti, četvrti sloj vrši smenu percepcije približavanjem i udaljavanjem - od grada kao celine, ka njegovim pojedinačnim prostornim vrednostima i specifičnim aspektima. Analiza se završava sa (de)fragmentisanim čitanjem putem crteža kao kritičkog alata za rešavanje prostornih konflikata. Sloj po sloj, preložena metodologija utvrđuje uticaj fenomena transparentnosti na arhitektonski proces projektovanja, kao i njegov značaj za promišljanje i razumevanje problema i potencijala transformacija gradskog pejzaža.

KLJUČNE REČI: TRANSFORMACIJE GRADSKOG PEJZAŽA, TRANSPARENTNOST, FENOMENOLOŠKA REDUKCIJA, (DE) FRAGMENTACIJA, PRESEK

\section{FILOZOFIJA ARHITEKTURE U ANALITIČKOJ FILOZOFIJI: Istraživanje mogućnosti polja i tema}

\section{Becheru Raluca}

Ovaj rad je usmeren na novo polje filozofije arhitekture u analitičkoj filozofiji. Istraživanje predstavljeno u ovom radu je deo istraživanja u okviru doktorske disertacije na temu povezanosti etike i estetike u arhitekturi. Veza između arhitekture i filozofije nije novina. Teorija arhitekture se oduvek ugledala na filozofiju, ali tek nedavno su filozofi počeli da izučavaju arhitekturu detaljnije. Teorija arhitekture je još uvek oblast koja je u potrazi za boljim konceptualnim okvirom nakon neuspeha teorijskih premisa modernog pokreta i uspona „teorijskog govora“. Odlika arhitekture kao javne umetnosti traži određenu objektivnost, te filozofija arhitekture u okvirima analitičke filozofije može doprineti postavljanju objektivnijeg konceptualnog okvira. Ključne teme povezane su sa pitanjima kontinentalne filozofije: šta čini arhitekturu posebnom među umetnostima, šta je suština arhitektonskog dela, kako bolje definisati socijalnu misiju arhitekture, dok je način dolaska do odgovora drugačiji. Etička dimenzija arhitekture je jedan od najčešće diskutovanih tema među arhitektima u poslednjih nekoliko godina, te se došlo do nekoliko argumentovanih zaključaka o vezi između etike i estetike u filozofiji arhitekture u analitičkoj filozofiji, koji imaju potencijal da ostvare uticaj na arhitektonsku teoriju i praksu.

KLJUČNE REČI: FILOZOFIJA ARHITEKTURE, ANALITIČKA FILOZOFIJA, TEORIJA ARHITEKTURE 